\title{
KEPEMIMPINAN TRANSFORMATIF DALAM PENGEMBANGAN MANAJEMEN MADRASAH BERORIENTASI MUTU
}

\author{
Arief Sukino \\ Dosen pada Fakultas Tarbiyah dan Ilmu Keguruan IAIN Pontianak \\ e-mail:ariefsukino@gmail.com.
}

\begin{abstract}
Abstrak
Artikel ini ditulis untuk mengajak para praktisi pendidikan Islam agar merevitalisasi manajemen dan kepemimpinan lembaga pendidikan Islam (madrasah) dalam menghadapi arus globalisasi yang diduga akan menggilas nilai-nilai esensial dari kehidupan umat Islam. Madrasah merupakan harapan masyarakat muslim dalam membentuk akhlak mulia, maka dari itu madrasah harul tampil lebih kokoh agar mampu mewujudkan harapan masyarakat. Dalam rangka menuju harapan itu madrasah perlu didukung oleh sumber daya yang ungul. Upaya yang sangat mendesak adalah dengan melakukan perubahan manajeman madrasah menjadi salah satu misi yang harus direalisasikan secara cepat. Sedangkan perubahan kepemimpinan madrasah sebagai instrument yang akan mewujudkan konsep manajemen tersebut. Dalam artikel ini dibahas hal-hal yang sangat fundamental terkait dengan implementasi School Based management (SBM) dan kepemimpinan transformatif yang mengasumsikan efektifitas dan efesiensi lembaga untuk menuju madrasah yang bermutu.
\end{abstract}

Kata kunci: Madrasah, manajemen dan kepemimpinan Tranformatif

\section{Abstract}

This article was written to encourage the practitioners of Islamic education in order to revitalize the management and leadership of Islamic educational institutions (madrasas) in the face of globalization is expected to run over the essential values of the life of Muslims. 
Madrasah is the hope of the Muslim community in the form of noble character, then from the madrassas must rise in order to be able to realize the expectations of society. In order to hope that madrassas need to be supported by the resources prefetch queue. Urgent efforts is by making changes to the madrassa management became one of the missions that must be realized quickly. While the change in the leadership of the madrassa as an instrument that would embody the concept of management. In this article discussed matters of fundamental importance related to the implementation of the School Based Management (SBM) and transformative leadership that assumes the effectiveness and efficiency of the institution towards quality madrasah.

Key Word: Madrassah, Management, Stransformative leadership

\section{A. Pendahuluan}

Pada era globalisasi, kemajuan sekolah/madrasah merupakan esensi dari pengelolaan sekolah melalui pemeliharaan mutu, responsif terhadap tantangan dan antisipatif terhadap perubahan-perubahan yang serba cepat dan menjadikan gejolak dalam kehidupan. Hal ini memacu dan mendorong para praktisi, birokrat, dan akademisi pendidikan untuk berpacu mengembangkan strategi perubahan dan kebijakan antisipatif sehingga mampu menyesuaikan diri dengan tuntutan baru dengan tetap memegang teguh nilai-nilai jati diri bangsa yang terpelihara. Globalisasi memberikan warna tersendiri bagi arah pencapaian tujuan pendidikan.

Sejalan dengan arus berubahan di atas pemerintah sebenarnya telah mengubah system pendidikan dengan memberikan otonomi daerah, otonomi ini didiberikan pada tingkat sekolah dengan anggapan bahwa sekolah sebagai lembaga tempat penyelenggaraan pendidikan yang merupakan sebuah sistem dengan memiliki berbagai perangkat dan unsur yang saling berkaitan. Secara internal sekolah memiliki perangkat guru, murid, kurikulum, sarana dan prasarana. Sementara secara eksternal sekolah memiliki hubungan dengan instansi lain baik secara vertikal maupun horisontal yang ditujukan untuk mencapai tujuan pendidikan.

Dengan demikian sekolah merupakan organisasi penyelenggara pendidikan yang langsung berhubungan dengan pihak-pihak yang berkepentingan (stakeholder) sehingga sekolah lebih mengetahui kekuatan, 
kelemahan, peluang maupun ancaman yang dihadapinya. Oleh karena itu perumusan kebijakan dan pengambilan keputusan harus melibatkan sekolah sebagai penyelenggara terdepan dalam proses pendidikan. Otonomi pengelolaan sekolah mengandung arti bahwa sekolah diberi keleluasaan dalam mengelola sumber dayanya sesuai dengan prioritas kebutuhan sekolah. Sehingga otonomi sekolah merupakan suatu upaya menampilkan kemandirian sekolah melalui pemberdayaan semua potensi yang tersedia ditujukan untuk meningatkan mutu pendidikan. Peningkatan mutu pendidikan itu melalui kemandirian dan inisiatif sekolah dalam mengelola dan memberdayakan sumber daya yang tersedia. Hal itu akan terwujud apabila didukung secara optimal oleh kepemimpinan yang mampu menyususn strategi dan adaptasi yang cepat. ${ }^{1}$

Saat ini, lembaga pendidikan khususnya yang madrasah khususnya lagi madrasah swasta sedang dihadapkan dengan persoalan yang sangat pelik dan mendasar baik intern maupun ekstern. Banyak pakar menilai kelemahan pendidikan Islam selama ini telah meliputi seluruh sistem pendidikan, baik menejemen, etos kerja, kuantitas dan kualitas guru, kurikulum serta sarana dan prasarana yang kurang memadai. Para pengelola juga belum memahami dan mengaktualisasikan manejemen yang benar, sehingga pengelolananya masih cenderung apa adanya, stagnan, statis, dan tidak berusaha melakukan inovasi-inovasi pengembangan.

Kepala madrasah merupakan personel pendidikan yang memiliki peran besar dalam mencapai keberhasilan pengelolaan madrasah. Kualitas kepemimpinan kepala madrasah yang kuat, di dalamnya termasuk pula kepribadian, keterampilan dalam menangani masalah yang timbul di madrasah, kemampuan dalam menjalin hubungan antar manusia sangat menentukan dan memiliki pengaruh yang besar terhadap kegagalan atau keberhasilan lembaga pendidikan. ${ }^{2}$

Dalam hal ini keberhasilan kepala madrasah dalam memimpin madrasah tampak dari apa yang dikerjakannya. Hal ini penting untuk dikedepankan

\footnotetext{
1 Aan Komariah dan Cepi Triatna, Visionary Leardership Menuju Sekolah Efektif (Jakarta: PT. Bumi Aksara, 2005), h. 81.

2 Miftah Thoha, Kepemimpinan dalam Manajemen (Jakarta: Rajawali Pers, 2012),h.1.
} 
karena apa yang dikerjakan kepala madrasah melalui kebijaksanaan yang telah ditetapkan akan dipengaruhi kondisi fisik dan psikis guru dan karyawan lainnya. Guru akan dapat melaksanakan tugas dengan penuh tanggung jawab apabila ia merasa puas terhadap kepemimpinan kepala madrasah. Oleh karena itu, efektifitas kepemimpinan kepala madrasah dalam mengelola madrasah merupakan kunci keberhasilan pengelolaan madrasah. Prestasi kerja guru dan karyawan merupakan hal yang tidak boleh diabaikan dalam mengukur efektifitas kepemimpinan kepala madrasah dalam mengelola madrasah yang dipimpinnya. Dengan adanya kepemimpinan kepala madrasah yang efektif, diharapkan semangat dan gairah kerja guru dan karyawan akan meningkat. Pada gilirannya akan meningkat pula produktivitas kerja guru dan karyawan sehingga akan terhindar dari tindakan-tindakan yang merugikan.

Kepemimpinan kepala madrasah dalam mengelola madrasah merupakan kunci utama bagi keberhasilan manajemen madrasah. Dengan demikian, Kepala Madrasah bertugas untuk mengkoordinasikan dan mengintegrasikan seluruh komponen dalam sistem madrasah. Kepala madrasah merupakan tenaga profesional yang memiliki kewenangan untuk memajukan dan mengembangkan madrasah, sehingga mampu menghadapi suasana kompetitif di tengah era globalisasi seperti sekarang ini.

Kepala Madrasah sebagai pimpinan madrasah memikul tanggung jawab yang amat besar untuk memenuhi harapan dari berbagai pihak yang terkait. ${ }^{3}$ Dengan mengemban tugas pokok Pendidikan Nasional, maka kepala madrasah dituntut untuk mampu mengarahkan, mengatur, memberi teladan anak buahnya untuk mencapai tujuan bersama yang telah ditetapkan. Keberhasilan dan ketidakberhasilan madrasah dalam mencapai tujuan sangat ditentukan oleh berhasil tidaknya kepala madrasah mengatur atau mengelola madrasah atau seluruh potensi madrasah agar berfungsi optimal dalam mendukung tercapainya tujuan madrasah.

Berdasarkan fakta permasalahan tersebut diatas factor kepemimpinan menjadi centran kebuntuan madrsah dalam menyelesaikan berbagai problem yang mendasar tersebut. Hal ini dapat dilihat bahwa kepemimpinan madrasah

Prof. H.E. Mulyasa, Manajemen dan Kepemimpinan Kepala Sekolah. Jakarta:Bumi Aksara, 2012 h. 181 
belum bergerak kepada model kepemimpinan modern yang mampu membawa organisasi menuju pencapaian hasilyang maksimal. Pemimpin madrasah kebanyakan dipilih berdasarkan kharismatik, ketuaannya, kepemilikan asset, atau pengaruh kekuasaan di dalam social masyarakatnya.

Berdasarkan gambaran tantangan madrasah kedepan kiranya madrasah saat ini perlu reorientasi model kepemimpinannya. Dalam hal ini model yang perlu dilakukan adalah model tranformatif. Model ini telah banyak dilakukan di sekolah-sekolah modern yang telah membuktikan keunggulannya dalam bidang pendidikan. Dalam kesempatan ini penulis akan memaparkan secara lebih dalam tentang implikasi kepemimpinan transformative dalam meningkatkan produktivitas madrasah yang sedang berkembang. Namun untuk kepentingan sistematika kajian maka penulis akan membahas hal-hal sebagai berikut 1) Bagaimanakah seharusnya pengembangan manajemen madrasah yang bermutu? 2) kepemimpinan transformative sebagai implementasi manajemen bermutu.

\section{B. Pengembangan Manajemen Madrasah}

Mengapa perlu pengembangan manajemen madrsah? Pertanyaan ini tentunya harus dijawab dari kerangka filosofis tentang kedudukan dari lembaga pendidikan Islam. Perlu diketahui bahwa lembaga pendidikn islam itu masuk dalam dua kategori, yakni kategori lembaga industry mulia (noble industry) yakni misi profit dan misis social, misi social bertujuan untuk mewariskan nilai-nilai luhur. Untuk mencapai misi tersebut lembaga pendidikan Islam (seperti Madrasah) perlu memiliki human capital dan social capital yang memadahi dan memiliki efektifitas dan efesisnsi yang tinggi ${ }^{4}$. Maka dari itu mengelola madrasah sangat membutuhkan orang yang professional dan juga niat suci-lapangdada, jujur ikhlas jiwa berkorban..

Masyarakat muslim pada umumnya sudah banyak yang mengetahui bahwa madrasah adalah lembaga pendidikan Islam yang di dalamnya mengajarkan pengetahuan agama penanaman nilai kehidupan dan juga sain. Maka bisa dikatakan bahwa masyarakat yang berminat sekolah di madrasah

4 Muhaimin dkk, Manajemen Pendidikan Aplikasi dalam penyususnan Renaca pengembangan Sekolab/ madrsah, Jakarta: Kencana cet 4 2012. H. 5 
paling tidak dengan dua alasan yang sangat mendasa yakni: pertama madrasah membekali siswa dalam aspek religiusitas yang lebih dibandingkan sekolah umum, kedua madrasah juga memberikan dasar dan pengembangan sain modern. Alasan tersebut sekaligus harapan masyarakat. Perlu diketahui bahwa awalnya madrasah berdiri atas inisiatif masyarakat sehingga madrasah hamper tidak mungkin terpisah dari masyarkat. Masyarakat masih beranggapan bahwa madrasah adalah tempat terbaik untuk membekali dan mengembangkan potensi anak didik untuk memperoleh bekal yang memadai untuk hidup bahagia di dunia dan akhirat.

Namun kenyataannya, tidak banyak madrasah yang menunjukkan prestasi di kedua bidang garapan tersebut, baik dalam ilmu umum maupun prestasi ilmu keagamaannya. Dalam bidang sains dan matematika, madrasah kalah bersaing dengan SMU dan dalam ilmu agama masih belum mampu bersaing dengan pesantren. Sekolah umum negeri, dengan pembiayaan, ketenagaan dan semua kebutuhan fasilitas tercukupi oleh pemerintah dibandingkan dengan prestasi madrasah yang pada umumnya berstatus swasta dan tidak memperoleh fasilitas sebagaimana yang diterima oleh sekolah umum pada umumnya. Perbandingan ini memang terasa idak adil namun tidak ada salahnya kita lakukan sebagai motivasi kepada pengelola madrasah agar terpacu andrenalinnya untuk menjadi penelola madrasah yang berkualitas dimasa sekarang dan seterusnya sehingga mampu bersaing bahkan mengungguli sekolah umum.

Masyarakat tentu terus berharap bahwa madrasah akan menjadi unggul. Untuk itu perlu ada perubahan dalam manajemen. Dari manajemen kepala rumah tangga ke manajemen perusahan. Sebagai jalan perubahan pengelolaannya yakni dengan menerapkan manajemen School Based Management.

Jadi tidak ada yang lebih baik lagi bagi madrasah yang sedang mulai tumbuh atau yang sedang mengalami krisis manajemen untuk segera mengadopsi pengalaman dari berbgai lembaga yang teah sukses. Berdasarkan hasil penelitian yang dilakukan diberbagai Negara manju ternyata konsep School Based Management (SBM) sebagai model baru dalam pengelolaan lembaga pendidikan telah terbukti mampu membawa perubahan pada peningkata mutu lulusan. 
Untuk lebih lanjutnya kan penulis paparkan secara lebih jelas dan dimulai dari pengertian dari SBM. Menurut para ahli seperti Allan Dornseif mengatakan: "School based management is a collection of practices which more people at the school level make decision for the school. SBM often begin with desentralization; a delegation of certain powers from central office to the school that may include any range of power from few, limited area to nearly every thing".

Definisi di atas dimaknai sebagai model manajemen yang memberikan otonomi lebih besar kepada sekolah dan mendorong pengambilan keputusan partisipatif yang melibatkan secara langsung semua warga sekolah (guru, siswa, kepala sekolah, karyawan, orang tua siswa, dan masyarakat) untuk meningkatkan mutu sekolah berdasarkan kebijakan pendidikan. Selain ahli di atas pakar dari Indonesia E. Mulyasa menegaskan bahwa SBM atau sering disebut leh orang Indonesia MBS, merupakan salah satu wujud dari reformasi pendidikan yang menawarkan kepada sekolah untuk menyediakan pendidikan yang lebih baik dan memadai bagi para peserta didik. Hal ini mengisaratkan, bahwa Otonomi dalam manajemen merupakan potensi bagi sekolah untuk meningkatkan kinerja para staff, menawarkan partisipasi langsung kelompokkelompok yang terkait, dan meningkatkan pemahaman masyarakat terhadap pendidikan $^{6}$

Dapat juga dimaknai suatu pendekatan politik yang bertujuan untuk melakukan redesain terhadap pengelolaan sekolah dengan memberikan kekuasaan pada kepala sekolah dan meningkatkan partisipasi masyarakat dalam upaya perbaikan kinerja sekolah yang mencakup guru, siswa, kepala sekolah, orang tua siswa, dan masyarakat. suatu perubahan dalam pengelolaan sekolah yang meningkatkan kewenangan semua pemangku kepentingan di lokasi sekolah dan di komunitas sekolah ${ }^{7}$

Setelah diketahui definsi tersebut maka akan dijelaskan apa sebenarnya tujuan dari SBM. SBM bertujuan

\footnotetext{
5 Allan DornseifSchool Based Management, Assosiation for supervision and Curriculum development ,Alexandria, Virginia, , 1996 , hal. iii

6 E. Mulyasa, 2004. Manajemen Berbasis Sekolah: Konsep, Strategi dan Implementasi Bandung: PT. Remaja Rosda Karya. 24

7 Malen, B., Ogawa, R.T., \& Kranz, J. (1989, May). What do we know about school based management? A case study of the literature- a call for research. Paper presented at the conference on choice and control in American education, University of Wisconsin- Madison, May 17-19.
} 
1. Meningkatkan mutu pendidikan melalui kemandirian dan inisiatif sekolah dalam mengelola dan memberdayakan sumber daya yang tersedia

2. Meningkatkan kepedulian warga sekolah dan masyarakat dalam penyelenggaraan pendidikan melalui pengambilan keputusan bersama/partisipatif.

3. Meningkatkan tanggung jawab sekolah kepada orang tua masyarakat dan pemerintah tentang sekolahnya.

4. Meningkatkan kompetensi yang sehat antar sekolah tentang mutu pendidikan yangakan dicapai.

Dari tujuan di atas dapat dikarakteristik lebih jelas lagi tentang gambaran mutu proses dalam SBM sebagai berikut.

1. Proses Belaja Mengajar yang efektifitasnya tinggi . Proses belajar mengajar yang menekankan pada bekerja, belajar hidup bersama dan belajar menjadi diri sendiri.

2. Kepemimpinan sekolah yang tangguh. Kepala sekolah memiliki kemampuan dan kepemimpinan yang tangguh, kuat dan mampu meningkatkan mutu sekolah sesuai dengan visi, misi tujuan dan sasaran yang telah ditetapkan.

3. Lingkungan sekolah yang tertib, aman, dan nyaman.

4. Pengelolaan tenaga pendidikan yang efektif. Kebutuhan tenaga, analisis, perencanaan, pengembangan, evaluasi, hubungan kerja.

5. Sekolah memiliki budaya mutu. Sekolah memiliki kualitas informasi untuk perbaikan hasil diikuti penghargaan atau sanksi, warga merasa aman, warga sekolah merasa memiliki sekolah.

6. Sekolah memiliki kebersamaan yang kompak. Sekolah memiliki budaya kerjasama antar individu tanpa adanya kelompok-kelompok tertentu yang dapat menghambat kemajuan sekolah.

7. Sekolah memiliki kewenangan. Kewenangan sekolah merupakan kesanggupan kerja dan tidak menggantungkan orang lain. Kepala sekolah mempunyai kreatifitas yang tinggi untuk menuju sekolah yang lebih baik. 
8. Partisipasi warga sekolah dan masyarakat. Hubungan antara sekolah dan masyarakat merupakan bagian kehidupan sekolah yang paling tinggi terutama di bidang non akademik dan akademik

9. Keterbukaan (transparasi) manajemen. Masalah manajemen perlu keterbukaan antara warga sekolah dan masyarakat terutama komite sekolah.Apalagi manajemen tersebut menyangkut perencanaan anggaran (RAPBS) dan penggunaan uang sekolah. Komite sekolah harus tahu terutama menyangkut anggaran sekolah. Contoh : DOP, BOS, Block Grant, dan anggaran rutin sekolah

10. Sekolah memiliki kemauan untuk berubah Perubahan sekolah diharapkan menuju yang lebih baik. Perubahan tersebut dapat berupa perubahan fisik sekolah, prestasi akademik dan non akademik.

11. Sekolah melakukan evaluasi dan perbaikan. Evaluasi bukan sekedar untuk memenuhi daya serapp siswa menerima pelajaran. Namun, evaluasi dapat dipakai tolak ukur untuk meningkatkan mutu sekolah pada proses belajar mengajar selanjutnya. Sekolah harus selalu melaksanakan evaluasi secara terus menerus baik berupa pengayaan dan perbaikan untuk siswa demi peningkatan mutu di sekolah.

12. Sekolah responsif dan antisipatif terhadap kebutuhan. Sekolah harus mampu mengantisipasi setiap kejadian yang adaa di sekolah terutama menyangkut mutu sekolah. Sekolah tidak pasif melainkan anatisipatif mencari ke sekolah sekolah lain atau ke lembagalemabaga pendidikan dengan kata lain menjemput bola demi kemajuan sekolah

13. Sekolah memiliki komunikasi yang baik. Sekolah memiliki komunikasi yang baik terutama antara warga sekolah. Kebersamaan antar warga sekolah dapat mengantar sekolah ke hal-hal yang lebih bermutu. Contoh Kelompok Kerja Guru di setiap Gugus Sekolah.

14. Sekolah memiliki Akuntabilitas. Sekolah memiliki tanggung jawab atas keberhasilan pelaksanaan penyelenggaraan program sekolah. Akuntabilitas berbentuk laporan prestasi yang harus dilaporkan kepada pemerintah, orang tua, dan masyarakat. Berdasarkan laporan hasil program, pemerintah/ketua yayasan dapat menilai 
apakah program MBS dapat mencapai tujuan atau tidak. Jika mencapai tujuan maka diberi penghargaan atau sebaliknya jika tidak berhasil perlu diberikan sanksi atau teguran atas kinerjanya yang tidak memenuhi syarat. Sedangkan para orang tua murid dapat memberikan penilaian terhadap program MBS yang dapat meningkatkan prestasi anak-anaknya atau kinerja sekolahnya. Jika ber- hasil orang tua dapat memberikan dorongan dan semangat kepada sekolah,atau sebaliknya jika tidak berhasil orang tua dapat meminta pertanggung jawaban dan penjelasan sekolah atas kegagalan yang telah dilakukan.

15. Manajemen sustainabilitas. Kemampuan menjaga kelangsungan hidupnya baik dalam program maupun pendanaannya, madrasah mampu menggali sumber dana dari masyarakat dan tidak mengantungkan subsidi dari pemerintah. ${ }^{8}$

Untuk dapat mengimplementasikan konsep (SBM) ini perlu adanya perubahan yang mendasar yakni:

1. Penganggaran muliti aksi. Artinya bahwa madrasah dalam penganggaran bukan hanya bersifat rutin raja namun harus menyentuh pada aktivitas untuk inovasi bagi madrasah, guru dan siswa. Dana semacam ini di sebut dana non-budgeter

2. Mekanisme pengambilan keputusan. Dalam pelaksanaannya SBM kepala madrasah merupaka actor utama dalam pengambilan keputusan. Jadi efektif tidanya keputusan kepala madrasah dintentukan oleh analisa terhadap sesuatu dan juga wisdom yang dimiliki kepala madrasah dan juga mempertimbangkan aspiraasi dari semua anggota mardasah.

3. Pengembangan sisitem pendukung. Bagian penting dari SMB adalah madrasah perlu dukungan dari organisasi profesi dan juga anggota masyarakat.

8 Dr. Ara Hidayat dan Imam Mahali, Pengelolaan pendidikan: Konsep, pronsip dalam mengelola Sekolah dan Madrasah, Jogyakarta:kaukaba, 2012, h. 270-273 


\section{Kepemimpinan Transformasional (Transformational Leadership)}

Madrasah merupakan tulang punggung dari kokohnya bangunan agama Islam di Nusantara. Madrasah merupakan harapan masyarakat muslim dalam membentuk akhlak mulia, maka dari itu madrasah harul tampil lebih kokoh agar mampu mewujudkan harapan masyarakat. Dalam rangka menuju harapan itu madrasah perlu didukung oleh sumber daya yang ungul khususnya di level kepala madrasah. Hadirnya kepala madrasah yang berkompeten ini akan membawa lembaga menuju pengelolaan yang disebut dengan School Based Management (SBM) artinya sekolah berbasis manajemen. Madrasah sudah waktunya bangkit dari tidur yang tidak nyeyak itu. Bangun dengan perubahan paradigm kepemimpinan yang enerjik,

\section{a. Pengertian Pemimpin}

Kata pemimpin dalam bahasa Inggris sering disebut leader dari akar kata to lead dan kegiatannya disebut kepemimpinan atau leadership. Dalam kata kerja to lead terkandung beberapa makna yang saling berhubungan erat yaitu bergerak lebih cepat, berjalan di depan, mengambil langkah pertama, berbuat paling dulu, mempelopori, mengarahkan pikiran/ pendapat orang lain, membimbing, menuntun, menggerakkan orang lain melalui pengaruhnya. Dengan demikian seorang pemimpin adalah oaring yang bergerak lebih awal, berjalan di depan, mengambil langkah pertama, berbuat paling dulu, mempelopori suatu tindakan, mengarahkan pikiran/pendapat, membimbing, menuntun, dan menggerakkan orang lain melalui pengaruhnya. ${ }^{9}$ Dalam Islam istilah kepemimpinan sering diidentikkan dengan istilah khilafah.

Pemimpin merupakan penggerak yang akan mengendalikan jalannya organisasi mencapai tujuan. Menurut Kotter kepeimpinan adalah seperangkat proses yang terutama ditunjukkan untuk menciptakan organisasi menyesuaikan dengan keadaan yang lebih cepat berubah mengarahkan kepada visi dan menginspirasi untuk mewujudkannya. ${ }^{10}$ Sementara menurut Robbins, ${ }^{11}$ kepemimpinan adalah kemampuan mempengaruhi suatu kelompok ke arah pencapaian tujuan.

\footnotetext{
Imam Suprayogo, Reformulasi Visi Pendidikan Islam (Malang: STAIN Press, 1999), hlm. 161

10 J.P. Kotter, Leading Change menjadi Pioner Perubahan, Jakarta:Gramedia 1997 h. 31

11 Robbins SP, Teori Pengembangan Organisasi, alih Bahasa Hadayana, Jakarta Bumi aksara 1996 h. 365
} 
Hasil penelitian menunjukkan diantaranya bahwa kepemimpinan dan motivasi berprestasi kepala sekola berpengaruh secara positif tehadap kinerja guru motivasi kerja dan kredibilitas kepala sekolah berkontribusi secara positif terhadap kinerja guru. Kepemimpinan merupakan energi pengggerak organisasi. Kepemimpinan juga merupakan energi yang dapat menggerakkan, menuntun dan menjaga aktifitas orang sehingga tujuan organisasi dapat tercapai. kepemimpinan merupakan suatu interaksi antara satu pihak sebagai pemimpin dengan pihak yang dipimpin. Kepemimpinan hanya ada dalam proses relasi seseorang dengan orang lain, sehingga tidak ada pengikut menyebabkan tidak ada pemimpin. Dengan demikian, pemimpin yang efektif harus mengetahui bagaimana membangkitkan inspirasi, memotivasi, dan bekerjasama dengan bawahannya. Sehingga, pemimpin pendidikan harus melakukan transformasi kepemimpinan dengan melakukan bimbingan, tuntunan dan anjuran kepada orang yang dipimpinnya agar tujuan lembaga dapat tercapai.

Kepemimpinan sangat berperan dalam pencapaian tujuan lembaga atau organisasi. Kepemimpinan yang amanah dan bertanggung jawab dapat membawa lembaga atau organisasi maju dan berkembang. Kepemimpinan juga sangat erat kaitannya dengan power atau kekuasaan. Kepemimpinan yang prospektif ditentukan oleh gaya dan kinerja pemimpin dari suatu lembaga atau organisasi. Pada lembaga pendidikan, pimpinan tertinggi dijabat oleh kepala sekolah, dekan, rektor dan sebagainya. Jabatan ini memerlukan beberapa persyaratan utama yang akan mempengaruhi, mengarahkan dan memimpin lembaga atau organisasinya untuk mencapai tujuan yang telah ditetapkan.

Kepemimpinan pendidikan berarti suatu kesiapan yang dimiliki seseorang dalam proses mempengaruhi, mendorong, membimbing, mengarahkan dan menggerakkan orang lain yang ada hubungannya dengan pelaksanaan dan pengembangan pendidikan dan pengajaran, agar segenap kegiatan dapat berjalan efektif dan efisien dalam pencapaian tujuan pendidikan dan pengajaran. ${ }^{12}$

12 Dr. Ara Hidayat dan Imam Mahali, Pengelolaan pendidikan: Konsep, pronsip dalam mengelola Sekolah 
Pemimpin yang profesional harus mempunyai kekuatan untuk memimpin bawahannya, sehingga efektif dalam pekerjaan yang diembannya. Pemimpin yang tidak efektif, tidak akan bisa mencapai tujuan lembaga atau organisasi secara baik. Menurut penulis, banyak ditemukan kepala sekolah, yang kurang berhasil melaksanakan tujuan lembaga dan organisasi. Salah satu indiaktornya adalah rendahnya prestasi belajar peserta didik. Selanjutnya, ditemukan kurang disiplinnya pendidik dan tenaga kependidikan di lembaga tersebut.

\section{b. Pengertian Pemimpin Transformatif}

Istilah transforming leadership digunakan pertama kali oleh James MacGregor Burns dalam bukunya yang diterbitkan tahun 1978, berjudul "Leadership" yang memenangkan hadiah Pulitzer. Menurut Burns, para pemimpin transformatif mengedepankan nilai-nilai moral para pengikut untuk meningkatkan keyakinan mereka tentang berbagai isu etika dan memobilisasi daya dan sumber daya mereka untuk mereformasi sesuatu. ${ }^{13}$ Dalam kaitannya dengan kepemimpinan transformasional, Bernard Bass (Stone et al, 2004) mengatakan sebagai berikut: "Transformational leaders transform the personal values of followers to support the vision and goals of the organization by fostering an environment where relationships can be formed and by establishing a climate of trust in which visions can be shared". ${ }^{14}$

Selain itu menurut Northouse, ${ }^{15}$ transformational leadership is a process that changes and transforms individuals In other words, transformational leadership is the ability to get people to want to change, to improve, and to be led it involves assessing associates' motives, satisfying their needs, and valuing them. kepemimpinan transformasional adalah proses bahwa perubahan dan mengubah individu. Dengan kata lain, kepemimpinan transformasional adalah kemampuan untuk mendapatkan orang untuk

dan Madrasah, Jogyakarta:kaukaba, 2012, h. 77 dan lihat juga Burhanudin, Analisis Administrasi Manajemen dan Kepemimpinan Pendidikan(Jakarta: Bumi Aksara, 1994), hlm. 64-65

13 McGregor Burns, Leadershi, New York: Harper \& Row 1978.

14 Bernard M. Bass dan Bruce J Avolio, Improving Organizational Effctiveness : Through Transformasional Leadership, New York: Sage Publication 1994

15 Northouse, Peter GLeadership Theory and Practice, second edition. Thousand Oaks, CA: Sage Publications, Inc. . 2001 
ingin mengubah, memperbaiki, dan dipimpin melibatkan menilai motif rekan ', memuaskan kebutuhan mereka, dan menghargai mereka.

Penerapan pola kepemimpinan transformasional dapat menunjang terwujudnya perubahan sistem kelembagaan. Menurut penulis, kepemimpinan transformatif merupakan salah satu gaya kepemimpinan yang cocok untuk diterpkan di lembaga pendidikan. Demikian ini diasumsikan akan mampu mewujudkan lembaga pendidikan yang berkualitas. Kepemimpinan yang bersifat transformasional memiliki penekanan dalam perwujudan visi dan misi, yang jelas, pengunaan komunikasi secara efektif, pemberian rangsangan intelektual, serta perhatian pribadi terhadap permasalahan individu anggota organisasinya. Dengan penekanan tersebut, pemimpin di lembaga pendidikan akan mampu meningkatkan kinerja stafnya dalam rangka mengembangkan kualitas lembaga.

Kepemimpinan transformasional menuntut pemimpin yang mampu berkomunikasi dengan baik, terutama komunikasi persuasive dengan pengikutnya memotivasi para bawahannya untuk melakukan tanggungjawab mereka lebih dari yang mereka harapkan. Pemimpin transformasional harus mampu mendefinisikan, mengkomunikasikan dan mengartikulasikan visi organisasi, dan bawahan harus menerima dan mengakui kredibilitas. Jadi, Esensi transformasi adalah mengubah potensi menjadi energi nyata. Pemimpin di lembaga pendidikan yang mampu melakukan transformasi kepemimpinan, berarti telah mampu mengubah potensi institusinya menjadi energi, untuk meningkatkan mutu proses dan hasil pendidikannya.

Dengandemikian, pemimpintransformasionalmerupakan pemimpin yang karismatik dan mempunyai peran sentral dan strategis dalam membawa organisasi mencapai tujuannya. Pemimpin transformasional juga harus mempunyai kemampuan untuk menyamakan visi masa depan dengan bawahannya, serta mempertinggi kebutuhan bawahan pada tingkat yang lebih tinggi dari pada apa yang mereka butuhkan. Jadi dapat ditegaskan bahwa pemimpin tranformatif itu pemimpin yang memiliki kompetensi 
1. Komitmen kepada visi dan misi lembaga. Ini diwujudkan dengan cara mengidentifikasi nilai-nilai, tujuan dan misi lembaga. Menunjukan model perilaku yang konsisten dengan nilai yang anutnya.

2. Berorientasi kepemimpinan pro aktif. Pemimpin yang dengan cepat menyiapkan perubahan bagi lembaga pendidikannya untuk mencapai tujuan. Menjado sosok yang siaga dalam memberikan pembinaan secara pribadi maupun kelompok

3. Ketegasan (desisiveness) menunjukkan dirinya yang siap mengambil keputusan dan yakin akan keputusannya dapat mencapai tujuan.

4. Sensitiimpin selalu memperhatihan perasaan orang lain, menyadari pengaruh dari perilaku keputusannya terhadap orang lain dalam kelompok.

5. Mengumpulkan informasi, menganalisis pembentukan konsep. Mengumpulkan latar belakang informasi terhadap suatu masalah sebelum membuat opini tentang suatu peristiwa.

6. Fleksibilitas Intelektual. Mampu menggunakan berbagai konsep dan pandangan dalam memecahkan masalah atau sedang mengambil kepputusan.

7. Persuasive atau mengatur interaksi. Kemampuan menstimulasi orang lain untuk bekerja sama. Dan berinteraksui dengan cara yang produktif-positif.

8. Beradaptasi secara taktis. Mampu menyesuaikan dan menerima strategi yang berbeda jika satu pendekatan khusus belum berhasil

9. Motivasi dan perhatian dalam pengembangan prestasi kerja tenaga pendidik dan kependidikan

10. Kontrol dan evaluasi. Memberikan umpan balik terhadap pekerjaan secara periodic dengan penjadwalan yang tepat.

11. Berorganisasi dan pendelegasian. Menyiapkan secara efisien pemanfaatan sumber daya manusia dan sumberlainnya

12. Komunikasi. Penyampaian gagasan secara pribadi secara jelas baik melalui tulisan maupun lisan. Menyampaikan gagasan secara genius dan tidak mengancam. Mampu menggunakan grafik, visual, dan symbol agar gagasan itu mencapai tujuan. 
Terkait dengan kompetensi di atas Menurut Yammarino dan Bass (1990), pemimpin transformasional harus mampu membujuk para bawahannya melakukan tugas-tugas mereka melebihi kepentingan mereka sendiri demi kepentingan organisasi yang lebih besar. Bass juga menyatakan bahwa pemimpin transformasional mengartikulasikan visi masa depan organisasi yang realistik, menstimulasi bawahan dengan cara yang intelektual, dan menaruh parhatian pada perbedaan-perbedaan yang dimiliki oleh bawahannya ${ }^{16}$. Dengan demikian, seperti keberadaan para pemimpin transformasional mempunyai efek transformasi baik pada tingkat organisasi maupun pada tingkat individu. ${ }^{17}$

Selain kompetensi sebagai seorang pemimpin lembaga pendidikan, pemimpin tranformasional secara umum juga harus memiliki kualifikasi yang distandarkan oleh lembaga yang berwenwng dalam hal ini adalah kementerian Pendidikan dan Kepemnterian Agama, kualifikasi standarnya adalah pedidikan minimal Sarjana, telah menjadi guru di madrasah tersebut dan memiliki pengalaman sekurang-kurangnya lima tahun. Hal ini dilakukan agar lembaga diasumsikan akan mengalami kemajuan dan meningkat kualitas pendidikannya

\section{c. Karakteristik Utama Kepemimpinan Tranformasional}

Setelah diketahui bagian dari kompetensi seorang pemimpin yang transformative di atas, maka ditemukan konsep tentang karakteristik kepemimpinan transformative sebagaimana ditulis Dalam buku yang berjudul "Improving Organizational Effectiveness through Transformational Leadership", Bass dan Avolio ${ }^{18}$ mengemukakan bahwa kepemimpinan transformasional mempunyai empat dimensi yang disebutnya sebagai "the Four I's".

1. Idealized influence (or charismatic influence) Idealized influence mempunyai makna bahwa seorang pemimpin transformasional

16 Bernard M. Bass, Leadership and Performance Beyond Expectation, New York: Free Press 1985

17 Penjelasan yang senada dengan pendapat diatas juga dapat dilihat dalam Gill, A., Fitzgerald, S., Bhutani, S., Mand, H., and Sharma, S. The Relationship Between Transformational Leadership and Employee Desire for Empowerment. International Journal of Contemporary Hospitality Management, Vol. 22 No. 2, 2010, pp. 263-273.

18 Bernard M. Bass dan Bruce J Avolio, Ibid 
harus kharisma yang mampu "menyihir" bawahan untuk bereaksi mengikuti pimppinan. Dalam bentuk konkrit, kharisma ini ditunjukan melalui perilaku pemahaman terhadap visi dan misi organisasi, mempunyai pendirian yang kukuh, komitmen dan konsisten terhadap setiap keputusan yang telah diambil, dan menghargai bawahan. Dengan kata lain, pemimpin transformasional menjadi role model yang dikagumi, dihargai, dan diikuti oleh bawahannya.

2. Inspirational motivation Inspirational motivation berarti karakter seorang pemimpin yang mampu menerapkan standar yang tinngi akan tetapi sekaligus mampu mendorong bawahan untuk mencapai standar tersebut. Karakter seperti ini mampu membangkitkan optimisme dan antusiasme yang tinggi dari pawa bawahan. Dengan kata lain, pemimpin transformasional senantiasa memberikan inspirasi dan memotivasi bawahannya.

3. Intellectual stimulation. Intellectual stimulation karakter seorang pemimpin transformasional yang mampu mendorong bawahannya untuk menyelesaikan permasalahan dengan cermat dan rasional. Selain itu, karakter ini mendorong para bawahan untuk menemukan cara baru yang lbih efektif dalam menyelesaikan masalah. Dengan kata lain, pemimpin transformasional mampu mendorong (menstimulasi) bawahan untuk selalu kreatif dan inovatif.

4. Individualized consideration Individualized consideration berarti karakter seorang pemimpin yang mampu memahami perbedaan individual para bawahannya. Dalam hal ini, pemimpin transformasional mau dan mampu untuk mendengar aspirasi, mendidik, dan melatih bawahan. Selain itu, seorang pemimpin transformasional mampu melihat potensi prestasi dan kebutuhan berkembang para bawahan serta memfasilitasinya. Dengan kata lain, pemimpin transformasional mampu memahami dan menghargai bawahan berdasarkan kebutuhan bawahan dan memperhatikan keinginan berprestasi dan berkembang para bawahan. 
Kepemimpinan transformasional adalah kemampuan seorang pemimpin dalam bekerja dengan dan/atau melalui orang lain untuk mentransformasikan secara optimal sumber daya organisasi dalam rangka mencapai tujuan yang bermakna sesuai dengan target capaian yang telah ditetapkan. Sumber daya dimaksud dapat berupa pimpinan, staf, bawahan, guru, fasilitas, dana, dan faktor-faktor keorganisasian.

Pemahaman akan pentingnya hasil usaha harus diterapkan kepada para pegawai. Dengan kata lain, orientasi proses mendapat prioritas dibandingkan dengan sekedar hasil. Kemudian, penekanan untuk mendahulukan kepentingan kelompok dibandingkan dengan kepentingan pribadi menjadi krusial mengingat hubungan yang baik dan iklim kerja yang kondsif menjadi perhatian utama dalam penerapan gaya kepemimpinan ini. Selanjutnya, mengingat kebutuhan bawahan bukan hanya materi, maka seorang pimpinan harus mampu mendorong pegawai untuk mempunyai kebutuhan yang lebih tinggi sesuai dengan kapasitas mereka.

\section{Kesimpulan}

Pengembangan madrasah yang bermutu perlu mempersiapkan dan melaksanakan system manajemen berbasis sekolah. Sedangkan untuk mengimplementasikan SBM maddrasah perlu sosok pemimpin transformative. Untuk dapat secara efektif dalam memimpin lembaga pendidikan madrasah Seorang pemimpin harus mampu melakukan beberapa hal sebagai berikut:

a. Transformasi paradigma

1. Melaksanakan program menjadi merumuskan/melaksanakan program.

2. Keputusan terpusat menjadi keputusan bersama/partisipatif.

3. Ruang gerak terbatas menjadi ruang gerak fleksibel.

4. Sentralistik menjadi desentralistik.

5. Individual menjadi kerjasama

6. Basis birokratik menjadi basis professional

7. Diatur menjadi mandiri

8. Malregulasi menjadi deregulasi

9. Informasi terbatas menjadi informasi terbuka 
10. Boros menjadi efisien

11. Pendelegasian menjadi pemberdayaan

12. Organisasi vertical menjadi organisasi horizontal

b. Tranformasi Konsep menuju aksi

1. memahami visi dan misi organisasi;

2. memahami lingkungan organisasi melalui analisis lingkungan strategis (SWOT);

3. merumuskan rencana strategis organisasi;

4. menginternalisasikan visi, misi, kondisi lingkungan strategis, dan rencana startegis pada seluruh anggota organisasi;

5. mengendalikan rencana strategis melalui manajemen pengawasan yang tepat;

6. memahami kebutuhan para pegawai;

7. memahami kapasitas para pegawai;

8. mendistribusikan pekerjaan sesuai dengan kapasitas pegawai; dan

9. mengapresiasi hasil pekerjaan pegawai.

\section{DAFTAR PUSTAKA}

Aan Komariah dan Cepi Triatna, Visionary Leardership Menuju Sekolah Efektif (Jakarta: PT. Bumi Aksara, 2005

Allan Dornseif, School Based Management, Assosiation for supervision and Curriculum development, Alexandria, Virginia, 1996

Ara Hidayat dan Imam Mahali, Pengelolaan pendidikan: Konsep, pronsip dalam mengelola Sekolah dan Madrasah, Jogyakarta:kaukaba, 2012

Bernard M. Bass dan Bruce J Avolio, Improving Organizational Effctiveness :Through Transformasional Leadership, New York: Sage Publication 1994

Bernard M. Bass, Leadership and Performance Beyond Expectation, New York: Free Press 1985

Burhanudin, Analisis Administrasi Manajemen dan Kepemimpinan Pendidikan(Jakarta: Bumi Aksara, 1994 
Gill, A., Fitzgerald, S., Bhutani, S., Mand, H.and Sharma, S. The Relationship Between Transformational Leadership and Employee Desire for Empowerment. International Journal of Contemporary Hospitality Management, Vol. 22 No. 2, 2010

H.E. Mulyasa, Manajemen dan Kepemimpinan Kepala Sekolah. Jakarta:Bumi Aksara, 2012

H.E. MulyasaManajemen Berbasis Sekolah: Konsep, Strategi dan Implementasi Bandung: PT. Remaja Rosda Karya. 2004

Imam Suprayogo, Reformulasi Visi Pendidikan Islam (Malang: STAIN Press, 1999

J.P. Kotter, Leading Change menjadi Pioner Perubahan, Jakarta:Gramedia 1997

Malen, B., Ogawa, R.T., \& Kranz, J. What do we know about school based management? A case study of the literature- a call for research. Paper presented at the conference on choice and control in American education, University of Wisconsin- Madison, 1989, May

McGregor Burns, Leadershi, New York: Harper \& Row 1978.

Miftah Thoha, Kepemimpinan dalam Manajemen Jakarta: Rajawali Pers, 2012

Muhaimin dkk, Manajemen Pendidikan Aplikasi dalam penyususnan Renaca pengembangan Sekolah/madrsah, Jakarta: Kencana cet 42012.

Northouse, Peter GLeadership Theory and Practice, second edition. Thousand Oaks, CA: Sage Publications, Inc. . 2001

Robbins SP, Teori Pengembangan Organisasi, alih Bahasa Hadayana, Jakarta Bumi aksara 1996 